\title{
LEVERAGING FINANCIAL MANAGEMENT PERFORMANCE OF THE SPANISH AEROSPACE MANUFACTURING VALUE CHAIN
}

\author{
Rubén Elvira HERRANZ1, Pablo García ESTÉVEZ², \\ María Auxiliadora de Vicente y OLIVA ${ }^{3}$, Rahul DÉ ${ }^{4}$ \\ ${ }^{1}$ Department of Business Administration, I.E.B. Business School, \\ Alfonso XI Street, 6, 28014, Madrid, Spain \\ ${ }^{2}$ Department of Finance, CUNEF, Leonardo Prieto Castro Street, 2, 28040, Madrid, Spain \\ ${ }^{3}$ Department of Financial Economy, Rey Juan Carlos University (URJC), \\ Paseo de los Artilleros Street, 28032, Madrid, Spain \\ ${ }^{4}$ Department Qualitative Methods \& Information Systems, Indian Institute of Management \\ Bangalore, (IIMB), Bannerghatta Road, 560076, Bangalore, Karnataka, India \\ E-mails:1'ruben.elvira@claustro-ieb.es (corresponding author); ${ }^{2}$ pgestevez@cunef.edu; \\ 33aria.devicente@urjc.es; ${ }^{4}$ rahul@iimb.ernet.in
}

Received 5 March 2017; accepted 17 July 2017

\begin{abstract}
We study financial management performance during 2008-2013 for the Spanish aerospace manufacturing value chain and the links with managerial decisions. Data from company financial statements is analysed with Principal Component Analysis, Data Envelopment Analysis and an Artificial Neural Network. Top financial performers focus on liquidity management rather than on returns: both in the short term, by increasing levels of current assets and funding them with short-term liabilities, as well as increasing asset turnover; and in the long term, by aligning equity to non-current assets, while reducing asset and debt intensity levels. Only the manufacturing value chain is analysed, showing the potential for future research in related fields (e.g. value chain, country). Benchmarking and forecasting financial performance yields information and enables agility and accuracy in the strategy setting process. This study makes a unique contribution because it applies the scientific method where no previous related studies have done. It offers the novelty of using a single metric while Ratio Analysis requires multiple unweighted measures. We contribute by: (a) providing a method based on publicly information to benchmark and predict financial performance, thus offering benefits for aerospace stakeholders and academia; and (b) employing a big data sample that closely represents the population.
\end{abstract}

Keywords: market performance, market structure, aerospace, factor analysis, neural networks, data envelopment, financial management.

JEL Classification: L1, L620, C380, C450, D240. 


\section{Introduction}

Benchmarking the managerial decisions that drive financial performance in a sector yields important information for companies, associations, researchers, other related industries and governments. It is even more crucial for certain strategic sectors, such as the aerospace manufacturing sector. Lee et al. (2008) present a value chain for the aerospace manufacturing sector, which, for this study, we simplify into three main components: (a) engineering design, (b) manufacturing, assembly, integration and testing, (c) maintenance-repair-overhaul and services. It should be noted that airports, airlines, air traffic management service providers and financial companies are not covered in this study.

Spain identified the aerospace industry as a strategic sector, according to the following criteria: capability of driving the industrial ecosystem, growth potential and orientation to international markets (Ministry of Economy, Industry and Competitiveness 2010). When comparing the total industrial sector with the aerospace manufacturing sector in the period 2008-2013, Spain reports the following Compound Annual Growth Rate (CAGR) figures for: revenues $(-1.85 \%$ for industry and $1.25 \%$ for aerospace), employment $(-4.15 \%$ for industry and $0.89 \%$ for aerospace), imports $(-2.22 \%$ for industry and $21.23 \%$ for the aerospace) and exports (2.64\% for industry and $6.74 \%$ for the aerospace) (National Statistics Institute 2017) (Marketline 2012, 2014). Some other factors that differentiate the aerospace industry from other industries are: the dumping effect due to the military-defence dyad, delivery of high value added products and services, and high entry barriers (high investments, complex products, short series, long development lead times, and high pay back periods). It is also worth studying a sector that moves in the opposite direction to national industrial trends and actively contributes to Spanish economic recovery. Globally, aerospace manufacturers represent around $1.00 \%$ of the total industrial ecosystem employment and revenues (National Institute of Statistics 2017).

New aircrafts require financial decisions to be made across the value chain. This study focuses on the period 2008-2013 because it is the last period where there is significant activity in all phases of the value chain due to new product developments plus existing production and support. A brief summary of those new developments includes the Airbus A350 (maiden flight in 2013), Airbus A400M redesigns and production ramp-up (maiden flight in 2009 and first customer delivery in 2013), Boeing 737MAX (maiden flight in 2016), Boeing (maiden flight in 2010 and first customer delivery in 2012), Boeing 787 redesign and production ramp-up (maiden flight in 2009 and first customer delivery in 2011), Lockheed Martin F35 redesigns and production ramp-up (maiden flight in 2006 and first customer delivery in 2012). There was also a certain amount of turbulence during the 2008-2013 period due to the global economic crisis of 2008, sovereign debt crisis of 2010, fuel price fluctuation, commercial aviation M\&A, stagnation of government defence budgets, fluctuation in the air transport demand, appearance of new competitors and delays in the entry into service of new aerospace programmes.

The literature on the Spanish aerospace industry does not use a scientific methodological approach. It is mainly composed of consultancy firm white papers, yearly reports of aerospace associations and statistical data available from governmental and private 
sources. None of those reports addresses topics with practical and research implications, such as financial managerial patterns, financial performance and their relationship with managerial decisions taken, or attempts to forecast financial performance. Moreover, some of those reports use Ratio Analysis to draw conclusions, solely by explaining the value of each ratio. However, using multiple unweighted financial measures seems weak compared to a single, holistic metric (efficiency). Traditionally efficiency is mainly focused on operations, either following a production or an intermediation approach, though some studies make the novel proposal of applying such techniques to benchmark firms' financial management performance (Halkos, Tzeremes 2012; Sueyoshi, Goto 2010; Song et al. 2011). This study follows that novel approach.

Those facts provide the basis for the research objectives: (a) analysing patterns and benchmarks in managerial strategies through commonly-accepted financial and accounting metrics and their evolution over time; (b) measuring and analysing financial management performance with a single metric; (c) setting out the implications of financial management performance for managerial strategies; (d) defining a model to forecast the firm's financial management performance based only on information from financial statements.

The research model requires data on firm liquidity structure, capital structure, asset structure, company characteristics, firm performance and firm efficiency. It should be noted that the data on firm efficiency is the efficiency outcome from DEA, holistically combining the performance in terms of investors (proxied by Return on Equity), the market (proxied by Return on Sales) and operations (proxied by Return on Capital Employed). Long-term variables are used to capture general trends while certain short-term variables are used to depict fluctuations. This model has some advantages, such as the fact that it does not require proprietary databases. Furthermore, it is simple, reliable and robust, as it is based on widely-accepted concepts and metrics. On the contrary, it may be perceived as lacking accuracy, as general concepts and variables are used rather than industry-specific ones. This does, however, offer the advantage of making the model replicable in other locations, times and sectors, thus allowing case comparison. The study employs a big data sample that is quite close to the entire population. The analysis entails exploratory, descriptive and predictive phases. As such, an incremental process is employed, based on Principal Component Analysis (PCA), Data Envelopment Analysis (DEA) and an Artificial Neural Network (ANN).

The manuscript is organized as follows: section 1 reviews the available literature on the research problem; section 2 explains the research methodology used (the model and data analysis methods); section 3 discusses the sample; section 4 shows the data analysis and results. Finally, section 5 outlines the results and conclusions.

\section{Literature review}

This section outlines the literature found on the aerospace manufacturing industry. Sources used to build the model and underpinning the analysis methods are described in the relevant sections to clearly establish the link with the approach followed in this research. Previous papers relating to the Spanish aerospace industry tend to be white 
papers from consultancy firms, reports from aerospace associations or governmental sources, all of which broadly describe the industry using ratios and graphics but without following the scientific method. In addition, none of these papers focus on the financial management field.

Among the governmental sources, it is worth highlighting the report from the Spanish Ministry of Industry, Energy and Tourism (2016), which provides longitudinal analysis of SIC code 30.3 (air and spacecraft manufacturing) from 2005-2015. The sector is depicted through a set of metrics including number of companies, revenues, production, value added, productivity, number of employees, investment intensity, exports, imports and labour cost. The report also compares those metrics with other countries and more SIC codes within Spain to show how important the sector is for the national economy. Lastly, the report analyses the sector using company related metrics such as innovation, assets and liabilities levels, return on assets, return on equity and EBIT. Again, this is a general-purpose study and does not follow the scientific method. Also, it does not address topics such as financial management performance, and does not even grade or cluster the variables employed.

The governmental report from ICEX presents a longitudinal analysis of the aerospace industry (ICEX 2016). The period of study comprises the years from 2006 to 2015. The report compiles facts and figures on the market, aerospace clusters, industrial infrastructure and the main players. A novel aspect of this report is that it addresses industry drivers, though not from a scientific standpoint. It focuses on local strengths, international programmes, governmental support and human resources availability. Finally, it outlines business opportunities for investors.

The Spanish Association of Defence, Aeronautics and Space Technologies Companies (TEDAE 2014) publishes a yearly report with general figures about the sector from various years. It includes metrics such as number of employees, innovation expenditure, productivity, exportations, revenues and the contribution of aerospace and defence to GDP. However, it does not follow a scientific approach, and nor is financial management performance addressed. No ranking or clustering of variables could be found as proxies of industry drivers.

The Marketline white papers (2012), (2014) describe the market definition, geography, segmentation, value, forecast, leading companies' profiles and perform a Porter's five forces analysis. They also include a macroeconomic panel to frame the study. The studies cover the period from 2006 to 2014 and employ a number of financial metrics such as profit margin, revenue growth, asset growth, liabilities growth, debt-assets ratio, return on assets, revenues per employee and profit per employee. For some variables, the compound annual rate of change and compound annual growth rate is calculated. However, these studies do not identify the drivers of financial management, nor do they benchmark financial performance, or try to forecast it. 


\section{Research methodology}

The research objectives are tackled by developing a model, collecting the required data and analysing them with appropriate tools. Depending on the part of the study the unit of analysis, generically termed a Decision Making Unit (DMU), can be a company, the industry or the group of most efficient companies.

\subsection{Model}

The model considers asset structure, capital structure, liquidity structure, company performance (investors, market and operations axes) and company efficiency (meaning the output of DEA model). Table 1 describes the model in terms of its concepts, measurement variables and how to calculate them. The only information it requires is that provided in financial statements, which is an advantage for a number of reasons: (a) no proprietary databases are needed as data can always be gathered from free access sources that are audited by an independent third party organization; (b) the use of standard information and variables allows comparison; (c) scale effect is avoided because the measurement model relies on ratios (particularly important when applying the DEA model), and (d) simplicity, reliability and robustness is achieved by using commonlyaccepted financial concepts and metrics.

On the contrary, the process may be perceived as less accurate, locally speaking, as general concepts and variables are used rather than industry-specific ones. However, it makes the model more powerful because it may be replicable in other locations, times and sectors, allowing case comparison.

Those concepts and variables are selected after performing a literature review of secondary sources. Most of the articles in question study the relationship between capital structure, company performance, corporate governance model, country effect and shareholding effect. The variables most closely aligned with the objectives and sector, are selected, while others, are tailored as necessary to align with the specific characteristics of the aerospace manufacturing sector.

"Company age" is measured in the literature as the number of years since establishment (Madrid-Guijarro et al. 2011; Liargovas, Skandalis 2010). This model follows this approach. For "Company size", studies use the number of employees (Morgan et al. 2009; Madrid-Guijarro et al. 2011; Liargovas, Skandalis 2010), logarithm of total assets (Campello 2006; Wang et al. 2013) and logarithm of sales (Kayo, Kimura 2011; Margaritis, Psillaki 2010). However, in our model, we use market share due to the structural differences in the value chain (e.g. engineering vs MRO). The variable "Value Chain Position" is developed ad-hoc for the study. The "Infrastructure and resource intensity" variable is referred to variously in the literature as tangibility (Kayo, Kimura 2011; Margaritis, Psillaki 2010) or asset intensity (Hofmann, Lampe 2013). Nevertheless, it is always computed the same way and we adopt that calculation.

The model employs "Asset intensity" as found in the literature (Hofmann, Lampe 2013; Lampe, Hofmann 2014). The same is the case for "Assets turnover rate" (Hofmann, Lampe 2013; Delen et al. 2013; Shue et al. 2009; Tehrani et al. 2012; Halici, Umut 
Table 1. Research model

\begin{tabular}{|c|c|c|c|}
\hline $\begin{array}{l}\text { Concept } \\
\text { name }\end{array}$ & $\begin{array}{c}\text { Concept } \\
\text { description }\end{array}$ & $\begin{array}{l}\text { Measurement } \\
\text { variable }\end{array}$ & Formula \\
\hline \multirow{6}{*}{$\begin{array}{l}\text { Company } \\
\text { Effect }\end{array}$} & \multirow{6}{*}{$\begin{array}{l}\text { Company } \\
\text { profile }\end{array}$} & Company age & Company age $=2013-$ Foundation year \\
\hline & & \multirow{2}{*}{ Company size } & Sales $_{t}$ \\
\hline & & & Aerospace industry revenues ${ }_{t}$ \\
\hline & & $\begin{array}{l}\text { Value chain } \\
\text { position }\end{array}$ & $\left\{\begin{array}{l}1=\text { Engineering } \\
2=\text { MAIT (Manufacturing.Assembly. Test \& Integration) } \\
3=\text { Services } \\
4=\text { MRO } \\
5=\text { Engineering + MAIT + Services } \\
6=\text { Engineering + MAIT + Services + MRO }\end{array}\right.$ \\
\hline & & \multirow{2}{*}{$\begin{array}{l}\text { Infrastructure } \\
\text { and resource } \\
\text { intensity }\end{array}$} & Non current assets ${ }_{t}$ \\
\hline & & & 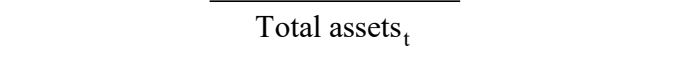 \\
\hline \multirow{6}{*}{$\begin{array}{l}\text { Asset } \\
\text { Structure }\end{array}$} & \multirow{6}{*}{$\begin{array}{l}\text { Capability of } \\
\text { the company to } \\
\text { configure short } \\
\text { and long term } \\
\text { level of assets } \\
\text { to produce } \\
\text { highest level of } \\
\text { sales }\end{array}$} & \multirow{2}{*}{ Asset intensity } & Non current assets $_{t}$ \\
\hline & & & Current assets ${ }_{t}$ \\
\hline & & \multirow{2}{*}{$\begin{array}{l}\text { Assets turnover } \\
\text { rate }\end{array}$} & Net sales $_{t}$ \\
\hline & & & ${\text { Total } \text { assets }_{\mathrm{t}}}$ \\
\hline & & \multirow{2}{*}{$\begin{array}{l}\text { Current assets } \\
\text { turnover rate }\end{array}$} & Net sales $_{t}$ \\
\hline & & & Current assets $_{t}$ \\
\hline \multirow{6}{*}{$\begin{array}{l}\text { Capital } \\
\text { Structure }\end{array}$} & \multirow{6}{*}{$\begin{array}{l}\text { Capability of } \\
\text { the company } \\
\text { to fund its } \\
\text { activities and } \\
\text { growth }\end{array}$} & \multirow{2}{*}{$\begin{array}{l}\text { Debt-to-Equity } \\
\text { ratio }\end{array}$} & Debt $_{t}$ \\
\hline & & & Equity $_{t}$ \\
\hline & & \multirow{2}{*}{ Leverage } & Debt $_{t}$ \\
\hline & & & 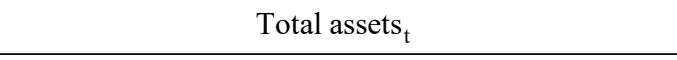 \\
\hline & & \multirow{2}{*}{ Debt intensity } & Non current liabilities $_{t}$ \\
\hline & & & Current liabilities $_{t}$ \\
\hline \multirow{4}{*}{$\begin{array}{l}\text { Liquidity } \\
\text { Structure }\end{array}$} & \multirow{4}{*}{$\begin{array}{l}\text { Capability of } \\
\text { the company } \\
\text { to meet its } \\
\text { obligations in } \\
\text { the short and } \\
\text { long term }\end{array}$} & \multirow{2}{*}{ Coverage ratio } & Equity $_{t}$ \\
\hline & & & Non current assets $t_{t}$ \\
\hline & & \multirow{2}{*}{ Current ratio } & 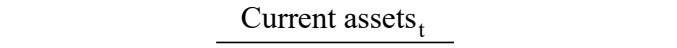 \\
\hline & & & Current liabilities $_{\mathrm{t}}$ \\
\hline \multirow{6}{*}{$\begin{array}{l}\text { Company } \\
\text { Perfor- } \\
\text { mance }\end{array}$} & \multirow{6}{*}{$\begin{array}{l}\text { Capability of } \\
\text { the company to } \\
\text { produce returns }\end{array}$} & \multirow{2}{*}{$\begin{array}{l}\text { ROE (Return } \\
\text { on equity) }\end{array}$} & Net income $_{t}$ \\
\hline & & & Equity $_{t}$ \\
\hline & & \multirow{2}{*}{$\begin{array}{l}\text { ROCE (Return } \\
\text { on capital } \\
\text { employed) }\end{array}$} & EBIT $_{t}$ \\
\hline & & & Capital employed $_{t}$ \\
\hline & & \multirow{2}{*}{$\begin{array}{l}\text { ROS (Return } \\
\text { on sales) }\end{array}$} & Net income $_{t}$ \\
\hline & & & Sales $_{\mathrm{t}}$ \\
\hline $\begin{array}{l}\text { Company } \\
\text { Efficiency }\end{array}$ & $\begin{array}{l}\text { Company } \\
\text { financial } \\
\text { management } \\
\text { performance }\end{array}$ & Efficiency & DEA efficiency (I / O orientation \\
\hline
\end{tabular}

Source: elaborated. 
Erham 2013; Lampe, Hofmann 2014) and "Current assets turnover rate" (Hofmann, Lampe 2013; Delen et al. 2013; Halici, Umut Erham 2013; Lampe, Hofmann 2014).

The literature reviewed uses the calculation debt divided by equity for "Debt-to-equity" (Hofmann, Lampe 2013; Ciampi, Gordini 2008; Lampe, Hofmann 2014) and we do the same for our research model. For "Leverage", a number of slightly different approaches are found. Most studies compute it as debt to the book value of total assets (Campello 2006) or using long-term debt to the sum of debt and book value of firm equity (Kayo, Kimura 2011) or foreign-earned income to net assets (Halici, Umut Erham 2013). Our model employs the former formulation. "Debt intensity" is calculated as non-current liabilities to current liabilities as in the literature reviewed (Mohd-Sulaiman 2013).

"Coverage ratio" is not as popular as many other variables when studying specific industries. However, we employ it here to specifically proxy willingness to invest in an industry requiring a high volume of non-current assets. Hofman and Lampe (2013), in their analysis the effect of financial statement decisions on company returns for logistic service providers, also use this variable, as equity to non-current assets. The "Current ratio" variable is commonly used in the literature in the form of current assets to current liabilities and we use the same formula in this study (Hofmann, Lampe 2013; Delen et al. 2013; Shue et al. 2009; Tehrani et al. 2012; Madrid-Guijarro et al. 2011).

" $R O E$ " is prevalent in the literature in the form of net income to equity (Shue et al. 2009; Ciampi, Gordini 2008; Tehrani et al. 2012; Madrid-Guijarro et al. 2011; Lampe, Hofmann 2014; Devinney et al. 2010). This research adopts the same formula. "ROCE" appears more frequently in the literature focusing on capital structure and firm performance. We employ the most common formula used in the reviewed literature and compute it as EBIT to capital employed (Vishnani, Shah 2007; Devinney et al. 2010). "ROS" is another popular financial ratio. Most of the authors reviewed follow the approach of calculating net income to sales (Shue et al. 2009; Morgan et al. 2009; Tehrani et al. 2012; Ciampi, Gordini 2008; Devinney et al. 2010), and we use the same formula. "Efficiency", measured as the result of DEA, is frequently used by authors (Azadeha et al. 2015; Kheirkhah et al. 2013; Tosun 2012). A novel approach is using this measure with a financial focus (Tehrani et al. 2012; Devinney et al. 2010), as we do in this paper.

\subsection{Data analysis methods}

A three-step process is applied; starting with PCA, followed by DEA and ending with ANN. Applying these techniques represents an inherent advantage, as they do not impose any additional requirements on the sample, such as normality, homoscedasticity, linearity or multicollinearity. The effect of normality increases in small samples leading to homoscedasticity; however, this is not the case with this study, which uses a big sample. Additionally, linearity is not the focus of the research objectives. Lastly, due to the nature of PCA, multicollinearity is desirable to a certain extent, as component rotations reveal the relationships where the variables make the greatest contribution to one of the components, while at the same time each component differs as much as possible from others. 
The joint application of PCA and DEA is widely used by many authors, including Adler and Yazhemsky (2010), Iyer and Banerjee (2016), Ho and $\mathrm{Wu}$ (2009). All of these authors first run DEA to compute efficiency, and the result is then included as another variable in the PCA analysis. Their focus is on using these two techniques to rank DMUs and comparing the results, looking for explanations for differences. This study takes a slightly different approach as PCA is used only to explore and rank the patterns of the industry bounded by the model dimensions, as well as its yearly evolution. Furthermore, DEA only computes the "Company Efficiency" variable, first to asses companies and secondly to be the output of the ANN.

Regarding the combination of DEA-ANN, it is commonly used for the same purpose as in this research, by authors such as Azadeha et al. (2015), Kheirkhah et al. (2013), Tosun (2012), and Yeh et al. (2010), who use DEA efficiency and financial ratios for predicting bankruptcy using a back-propagation neural network.

The three techniques do not all use the full set of model variables from Table 1. PCA does not use "Value Chain Position" and "Company efficiency". The rationale for not including the former is that the study focuses on depicting value chain trends as an aggregate rather than showing group differences; it should be noted that value chain groups are not homogenous in terms of population and this may bias the results of the comparison. Regarding the second, it has not yet been computed at this stage of the process. The "Company efficiency" variable represents the output of DEA, hence it is part of the next phase. Further analysis tackles group differences computing "Company efficiency" clustered by the "Value Chain Position" variable.

ANN does not include "Value Chain Position" and "Company age". There are two main reasons for not including the value chain position of a firm in the predictive model. On the one hand, in some parts of the value chain there is not a big enough number of companies to run an ANN model. On the other hand, even if enough data is available, leaving out this variable, means that efficiency can be predicted in such cases where a firm changes its position in the value chain, via upward or backward integration. This enhances the prediction capability of the model. The rationale for excluding "Company age" is an attempt to make this predictive model applicable to newcomers doing their market entry feasibility analysis. Therefore, by leaving out this variable, the applicability of the model is not constrained. On the contrary, the "Company size" variable is included in the ANN model to allow newcomers performing scenario analysis, using various market shares in accordance with the business plan hypothesis.

\section{Data}

The population contains 539 firms, incorporating those companies that hold an EN 9100 certification in their Quality Management System (Society of Automotive Engineers 2015), or that belong to national aerospace associations and clusters. On average, $54.24 \%$ of the population have their financial statements listed in the SABI $®$ database (Bureau Van Dijk 2015) for the 2008-2013 period. Multiple imputations of missing values and outlier deletion using the Tukey's univariate approach were used to set the sample for analysis, representing $43.44 \%$ of the population. Theoretically, the results 
could not therefore be generalized without running an inference test, however only nonrelevant and very small companies are left out. Hence, the results could be representative of the industry and the conclusions could be generally applicable. Table 3 shows the sample distribution segmented by value chain position. Note that a proprietary database is used only as a shortcut in the data collection effort and does not bias it. Otherwise the financial statements could be obtained free of charge from publicly-available sources.

\section{Analysis}

This section describes the application of the analysis techniques to the sample and presents the results.

\subsection{Principal component analysis (PCA)}

An adequacy test is run before sample analysis. The use of PCA is appropriate as the KMO index is over 0.500 in all years and very close in 2008, when it is 0.495 . Additionally, the Bartlett's Sphericity test shows there is significant correlation among variables, thus indicating the suitability of this technique, as shown in Table 2. The analysis is conducted on a yearly basis using Varimax rotation with Kaiser normalization.

Table 2. Industry structure and variation

\begin{tabular}{|c|c|c|c|c|c|c|c|}
\hline & & 2008 & 2009 & 2010 & 2011 & 2012 & 2013 \\
\hline \multirow{5}{*}{$\begin{array}{c}\text { Component } \\
1\end{array}$} & Infrastructure and resource intensity & 0.975 & 0.961 & 0.971 & 0.970 & 0.970 & 0.967 \\
\hline & Asset intensity & 0.940 & 0.919 & 0.935 & 0.929 & 0.939 & 0.932 \\
\hline & Coverage ratio & -0.709 & -0.697 & -0.736 & 0.755 & 0.737 & 0.709 \\
\hline & Debt intensity & 0.588 & 0.659 & 0.627 & -0.735 & -0.711 & -0.650 \\
\hline & Explicated variance & 26.481 & 26.597 & 27.168 & 28.931 & 29.919 & 29.428 \\
\hline \multirow{4}{*}{$\begin{array}{c}\text { Component } \\
2\end{array}$} & Leverage & 0.911 & 0.922 & 0.946 & 0.938 & 0.963 & 0.923 \\
\hline & Debt to equity ratio & 0.839 & 0.844 & 0.856 & 0.854 & 0.895 & 0.809 \\
\hline & Current ratio & -0.787 & -0.834 & -0.802 & -0.806 & -0.787 & -0.806 \\
\hline & Explicated variance & 16.421 & 18.590 & 20.064 & 21.556 & 20.956 & 22.654 \\
\hline \multirow{4}{*}{$\begin{array}{c}\text { Component } \\
3\end{array}$} & ROE & 0.921 & 0.948 & 0.905 & 0.928 & 0.944 & 0.932 \\
\hline & ROCE & 0.892 & 0.922 & 0.876 & 0.878 & 0.915 & 0.917 \\
\hline & ROS & 0.870 & 0.900 & 0.827 & 0.860 & 0.869 & 0.900 \\
\hline & Explicated variance & 15.572 & 15.631 & 14.132 & 19.305 & 19.636 & 19.233 \\
\hline \multirow{3}{*}{$\begin{array}{l}\text { Component } \\
4\end{array}$} & Current assets turnover rate & 0.920 & 0.926 & 0.950 & 0.952 & 0.960 & 0.979 \\
\hline & Assets turnover rate & 0.840 & 0.805 & 0.830 & 0.848 & 0.849 & 0.845 \\
\hline & Explicated variance & 13.009 & 12.205 & 10.782 & 12.816 & 13.910 & 11.914 \\
\hline \multirow{3}{*}{$\begin{array}{l}\text { Component } \\
5\end{array}$} & Company age & -0.613 & - & -0.838 & - & - & - \\
\hline & Company size & 0.470 & 0.705 & - & - & - & - \\
\hline & Explicated variance & - & - & - & - & - & - \\
\hline \multirow{3}{*}{$\begin{array}{c}\text { PCA } \\
\text { validity test }\end{array}$} & $\mathrm{KMO}$ & 0.495 & 0.538 & 0.552 & 0.526 & 0.527 & 0.545 \\
\hline & $\begin{array}{l}\text { Bartlett's Sphericity } \\
\text { Test Chi-Squared }\end{array}$ & 2995.993 & 3036.440 & 3063.580 & 2895.971 & 3096.053 & 2190.904 \\
\hline & $\begin{array}{l}\text { Bartlett's Sphericity } \\
\text { Test Significance }\end{array}$ & 0.000 & 0.000 & 0.000 & 0.000 & 0.000 & 0.000 \\
\hline
\end{tabular}

Source: elaborated. 
Table 2 displays the number of components, their composition in terms of model variables, the correlations among the variables and components plus the percentage of variance of each component in each year.

Five components are obtained with the same yearly configuration in terms of variables for all years, although this could be reduced to four, as the fifth component is not representative enough. This result shows stability in the underlying dynamics that explains on average $77.82 \%$ of the industry variance.

\subsection{Data envelopment analysis (DEA)}

This study follows a Constant Returns to Scale approach using a CCR and output oriented formulation. Yeh et al. (2010) adopt this approach for their study, in which financial ratios are also employed. We follow the same DEA linear programming model. It is expressed in Eq. (1). There are $n$ DMUs (Companies), each uses $m$ inputs (Company age, company size, infrastructure and resource intensity, asset intensity, asset turnover rate, current asset turnover rate, debt-to-equity ratio, leverage, debt intensity, coverage ratio and current ratio) to produce $s$ outputs (ROE, ROCE, and ROS). The index $k(k=1,2, \ldots, \mathrm{n})$ represents the DMU whose relative efficiency is to be maximized.

$$
\begin{aligned}
& \text { Max }: h_{k}=\frac{\sum_{r=1}^{s} u}{\sum_{i=1}^{m} v_{i k}} \\
& \text { s.t. } \\
& \frac{\sum_{r=1}^{s} u_{r} * Y_{r j}}{\sum_{i=1}^{m} v_{i} * X_{i j}} \leq 1 ; \\
& u_{r}, v_{i} \geq 0 ; \\
& i=1,2, \ldots, m ; \\
& r=1,2, \ldots, s ; \\
& j=1,2, \ldots, n .
\end{aligned}
$$

The objective function maximises the efficiency score, denoted by $h_{k}$. All DMUs, whose $h_{k}$ is 1 , represent the efficient frontier where the rest of DMUs are ranked using their $h_{k}$ score. The closer they are to the frontier, the more efficient. The $h_{k}$ is obtained comparing, the summation of the variable weights of the $r$-th output for the $k$-th DMU $\left(u_{r k}\right)$ multiplied by the output level of the $r$-th output for the $k$-th DMU $\left(Y_{r k}\right)$, with the summation of the variable weights of the $i$-th input for the $k$-th DMU $\left(v_{i k}\right)$ multiplied by the input level of the $i$-th input for the $k$-th DMU $\left(X_{i k}\right)$. This function is subject to non-negativity constrains for the input and output weights, plus the assumption of having positive $Y_{r j}$ (output level of the $r$-th output for the $j$-th DMU) and $X_{i j}$ (input level of the $i$-th input for the $j$-th DMU).

According to this approach, a company is more efficient than others if it is able to produce greater returns in terms of investors (ROE), operations (ROCE) and the market (ROS) with a given asset structure, capital structure, liquidity structure and certain company characteristics, that are comparable to those of the company in question. 


\begin{tabular}{|c|c|c|c|c|c|c|c|c|c|}
\hline & & Average & 2008 & 2009 & 2010 & 2011 & 2012 & 2013 & Trend Histogram \\
\hline \multirow{3}{*}{ Company age } & Industry & 18.909 & 17.967 & 18.534 & 18.292 & 18.690 & 19.976 & 19.994 & \\
\hline & Top 50 efficient & 17.333 & 17.588 & 15.549 & 15.255 & 17.039 & 20.529 & 18.039 & \\
\hline & Delta (Eff-Ind) & -1.575 & -0.378 & -2.985 & -3.037 & -1.650 & $\begin{array}{lll} & 0.554 \\
\end{array}$ & -1.955 & \\
\hline \multirow{3}{*}{ Company size } & Industry & 0.030 & 0.036 & 0.043 & 0.035 & 0.034 & 0.029 & 0.003 & \\
\hline & Top 50 efficient & 0.049 & 0.002 & 0.002 & 0.002 & 0.155 & 0.129 & 0.005 & \\
\hline & Delta (Eff-Ind) & $\begin{array}{lll} & 0.019 \\
\end{array}$ & - -0.034 & -0.041 & -0.033 & \begin{tabular}{lll|} 
& 0.121 \\
\end{tabular} & $0 \quad 0.100$ & $\begin{array}{lll} & 0.002\end{array}$ & \\
\hline \multirow{3}{*}{$\begin{array}{l}\text { Infrastructure } \\
\& \text { Resource } \\
\text { intensity }\end{array}$} & Industry & 0.388 & 0.379 & 0.382 & 0.372 & 0.396 & 0.404 & 0.396 & \\
\hline & Top 50 efficient & 0.326 & 0.309 & 0.302 & 0.290 & 0.354 & 0.352 & 0.351 & \\
\hline & Delta (Eff-Ind) & C -0.062 & - 0.070 & -0.080 & -0.082 & -0.042 & -0.053 & -0.045 & \\
\hline \multirow{3}{*}{ Asset intensity } & Industry & 0.845 & 0.816 & 0.822 & 0.784 & 0.881 & 0.904 & 0.862 & \\
\hline & Top 50 efficient & 0.685 & 0.675 & 0.550 & 0.581 & 0.776 & 0.788 & 0.738 & \\
\hline & Delta (Eff-Ind) & -0.160 & -0.141 & -0.272 & -0.203 & -0.105 & -0.117 & -0.124 & \\
\hline \multirow{3}{*}{$\begin{array}{l}\text { Asset turnover } \\
\text { rate }\end{array}$} & Industry & 1.007 & 1.044 & 0.979 & 0.994 & 0.971 & 1.017 & 1.040 & \\
\hline & Top 50 efficient & 1.130 & 1.113 & 1.160 & 1.248 & 1.054 & 1.049 & 1.156 & \\
\hline & Delta (Eff-Ind) & $\begin{array}{lll} & 0.122 \\
\end{array}$ & O 0.069 & $\begin{array}{lll} & 0.181 \\
\end{array}$ & $\begin{array}{lll} & 0.254 \\
\end{array}$ & \begin{tabular}{|ll|l|} 
& 0.083 \\
\end{tabular} & $0 \quad 0.032$ & $\begin{array}{lll} & 0.116 \\
\end{array}$ & \\
\hline \multirow{3}{*}{$\begin{array}{l}\text { Current assets } \\
\text { turnover rate }\end{array}$} & Industry & 1.698 & 1.748 & 1.633 & 1.626 & 1.666 & 1.769 & 1.747 & \\
\hline & Top 50 efficient & 1.704 & 1.703 & 1.622 & 1.780 & 1.663 & 1.654 & 1.803 & \\
\hline & Delta (Eff-Ind) & b $\quad 0.006$ & -0.044 & -0.011 & $\begin{array}{lll} & 0.154\end{array}$ & -0.003 & -0.114 & $\begin{array}{lll} & 0.056\end{array}$ & \\
\hline \multirow{3}{*}{$\begin{array}{l}\text { Debt to equity } \\
\text { ratio }\end{array}$} & Industry & 2.331 & 2.396 & 2.291 & 2.404 & 2.358 & 2.312 & 2.226 & \\
\hline & Top 50 efficient & 2.516 & 2.360 & 2.573 & 2.703 & 2.661 & 2.692 & 2.108 & \\
\hline & Delta (Eff-Ind) & $\begin{array}{lll}0 & 0.185 \\
\end{array}$ & -0.036 & $\begin{array}{|ll|} & 0.281 \\
\end{array}$ & $\begin{array}{|ll|}0 & 0.299 \\
\end{array}$ & $\begin{array}{|ll|}O & 0.303 \\
\end{array}$ & $\begin{array}{|ll|} & 0.380 \\
\end{array}$ & -0.117 & \\
\hline \multirow{3}{*}{ Leverage } & Industry & 0.619 & 0.630 & 0.603 & 0.619 & 0.625 & 0.614 & 0.620 & \\
\hline & Top 50 efficient & 0.618 & 0.620 & 0.597 & 0.628 & 0.626 & 0.619 & 0.616 & \\
\hline & Delta (Eff-Ind) & -0.001 & -0.010 & -0.006 & $\begin{array}{|ll|} & 0.009 \\
\end{array}$ & $\begin{array}{|ll|}\mathrm{O} & 0.001 \\
\end{array}$ & $\begin{array}{lll} & 0.005 \\
\end{array}$ & - -0.004 & \\
\hline \multirow{3}{*}{ Debt intensity } & Industry & 0.720 & 0.614 & 0.699 & 0.719 & 0.798 & 0.765 & 0.727 & \\
\hline & Top 50 efficient & 0.519 & 0.405 & 0.515 & 0.429 & 0.559 & 0.590 & 0.617 & \\
\hline & Delta (Eff-Ind) & -0.201 & -0.209 & -0.184 & -0.290 & -0.240 & -0.175 & - -0.110 & \\
\hline \multirow{3}{*}{ Coverage ratio } & Industry & 1.410 & 1.466 & 1.477 & 1.485 & 1.347 & 1.364 & 1.324 & \\
\hline & Top 50 efficient & 1.766 & 2.084 & 1.918 & 1.898 & 1.552 & 1.661 & 1.479 & \\
\hline & Delta (Eff-Ind) & \begin{tabular}{|lll} 
& 0.355 \\
\end{tabular} & \begin{tabular}{|lll}
0 & 0.618
\end{tabular} & $\begin{array}{ll} & 0.442 \\
\end{array}$ & $\begin{array}{|ll|} & 0.413 \\
\end{array}$ & $\begin{array}{|ll|}\mathrm{O} & 0.206 \\
\end{array}$ & $\begin{array}{ll} & 0.297 \\
\end{array}$ & $\begin{array}{|ll|} & 0.155 \\
\end{array}$ & \\
\hline \multirow{3}{*}{ Current ratio } & Industry & 1.745 & 1.637 & 1.796 & 1.819 & 1.756 & 1.744 & 1.716 & \\
\hline & Top 50 efficient & 1.797 & 1.718 & 1.979 & 1.848 & 1.725 & 1.714 & 1.797 & \\
\hline & Delta (Eff-Ind) & \begin{tabular}{|lll} 
& 0.052 \\
\end{tabular} & $\begin{array}{ll}0.081 \\
\end{array}$ & $\begin{array}{|ll|} & 0.184 \\
\end{array}$ & $\begin{array}{|ll|} & 0.029 \\
\end{array}$ & -0.031 & -0.030 & $\begin{array}{|ll|} & 0.081 \\
\end{array}$ & \\
\hline \multirow{3}{*}{ ROE } & Industry & 11.063 & 13.028 & 9.841 & 11.691 & 10.473 & 9.584 & 11.763 & \\
\hline & Top 50 efficient & 27.111 & 29.435 & 26.247 & 27.832 & 25.545 & 26.469 & 27.137 & \\
\hline & Delta (Eff-Ind) & $\mathrm{P}_{16.047}$ & $P_{16.407}$ & O 16.406 & $\mathrm{O}_{16.141}$ & $\mathrm{O}_{15.072}$ & $O_{16.884}$ & O 15.373 & \\
\hline \multirow{3}{*}{ ROCE } & Industry & 11.419 & 13.920 & 11.136 & 12.238 & 10.537 & 9.611 & 11.072 & \\
\hline & Top 50 efficient & 24.964 & 27.431 & 26.238 & 27.867 & 22.097 & 22.315 & 23.833 & \\
\hline & Delta (Eff-Ind) & D 13.545 & O 13.511 & O 15.101 & O 15.629 & O 11.560 & O 12.705 & $\mathrm{O} 12.762$ & \\
\hline \multirow{3}{*}{ ROS } & Industry & 4.221 & 4.806 & 3.887 & 4.174 & 4.202 & 3.906 & 4.351 & \\
\hline & Top 50 efficient & 10.091 & 10.464 & 10.656 & 9.416 & 9.795 & 10.448 & 9.765 & \\
\hline & Delta (Eff-Ind) & D 5.870 & D 5.658 & $\begin{array}{lll} & 6.769\end{array}$ & \begin{tabular}{|lll} 
& 5.242 \\
\end{tabular} & $\begin{array}{lll} & 5.593 \\
\end{array}$ & O $\quad 6.542$ & $\begin{array}{|ll|} & 5.414 \\
\end{array}$ & \\
\hline \multirow{3}{*}{$\begin{array}{l}\text { Company } \\
\text { efficiency }\end{array}$} & Industry & 0.490 & 0.522 & 0.522 & 0.493 & 0.509 & 0.475 & 0.419 & \\
\hline & Top 50 efficient & 0.979 & 1.000 & 1.000 & 0.992 & 1.000 & 0.999 & 0.880 & \\
\hline & Delta (Eff-Ind) & D 0.489 & D 0.478 & $\begin{array}{lll} & 0.478\end{array}$ & $\begin{array}{ll} & 0.499\end{array}$ & $\begin{array}{lll} & 0.491\end{array}$ & O & $\begin{array}{ll}\mathrm{O} & 0.461\end{array}$ & \\
\hline
\end{tabular}

Fig. 1. Industry-efficient companies group comparison

Source: elaborated. 
A comparison between top financial performers and the industry average is shown in Figure 1. For each model variable, the following information is provided on an average annual basis: industry mean, the top 50 efficient companies' mean and the difference between those two groups (Delta Eff-Ind. row). The rationale for selecting only 50 companies as the benchmark is that most of companies with an efficiency score of 1.000 are ranked in the top 50 positions. In some years, however, not all the top 50 companies have an efficiency score of 1.000; in 2010, for example, the average score for the top 50 is 0.992 , in 2012 it is 0.999 , and in 2013 it is 0.880 . Nevertheless, the best solution is to keep the top 50 as a group, as it does not jeopardize the results. In Figure 1, a white circle means a higher value for the top performers while a black circle indicates the opposite.

Additionally, Table 3 shows the financial performance results clustered by their value chain coverage.

The conclusions derived from Figure 1 and Table 3, are discussed in the next section.

Table 3. Financial performance of Spanish aerospace companies segmented by value chain position

\begin{tabular}{|c|c|c|c|c|c|c|c|}
\hline Value chain position & & 2008 & 2009 & 2010 & 2011 & 2012 & 2013 \\
\hline \multirow{3}{*}{ Engineering } & Mean & 0.548 & 0.608 & 0.577 & 0.550 & 0.446 & 0.452 \\
\hline & Std. Dev & 0.343 & 0.360 & 0.334 & 0.386 & 0.333 & 0.390 \\
\hline & $\mathrm{N}$ & 32 & 34 & 41 & 41 & 32 & 30 \\
\hline \multirow{3}{*}{ MAIT } & Mean & 0.480 & 0.452 & 0.447 & 0.469 & 0.479 & 0.389 \\
\hline & Std. Dev & 0.328 & 0.375 & 0.352 & 0.331 & 0.348 & 0.318 \\
\hline & $\mathrm{N}$ & 142 & 128 & 139 & 151 & 142 & 102 \\
\hline \multirow{3}{*}{ Services } & Mean & 0.654 & 0.574 & 0.504 & 0.571 & 0.428 & 0.471 \\
\hline & Std. Dev & 0.360 & 0.436 & 0.377 & 0.371 & 0.343 & 0.342 \\
\hline & $\mathrm{N}$ & 22 & 27 & 27 & 24 & 27 & 22 \\
\hline \multirow{3}{*}{ MRO } & Mean & 0.431 & 0.549 & 0.565 & 0.561 & 0.578 & 0.113 \\
\hline & Std. Dev & 0.372 & 0.397 & 0.265 & 0.442 & 0.387 & 0.193 \\
\hline & $\mathrm{N}$ & 5 & 5 & 5 & 5 & 6 & 3 \\
\hline \multirow{3}{*}{ Eng + MAIT + Services } & Mean & 0.605 & 0.647 & 0.567 & 0.562 & 0.495 & 0.455 \\
\hline & Std. Dev & 0.376 & 0.340 & 0.322 & 0.351 & 0.372 & 0.346 \\
\hline & $\mathrm{N}$ & 34 & 34 & 31 & 35 & 35 & 18 \\
\hline \multirow{3}{*}{ Eng + MAIT + Services + MRO } & Mean & 0.483 & 0.555 & 0.482 & 0.663 & 0.539 & 0.821 \\
\hline & Std. Dev & 0.239 & 0.382 & 0.404 & 0.405 & 0.411 & 0.135 \\
\hline & $\mathrm{N}$ & 5 & 4 & 5 & 5 & 4 & 3 \\
\hline \multirow{3}{*}{ Total } & Mean & 0.522 & 0.522 & 0.493 & 0.509 & 0.475 & 0.419 \\
\hline & Std. Dev & 0.342 & 0.381 & 0.349 & 0.350 & 0.348 & 0.338 \\
\hline & $\mathrm{N}$ & 240 & 232 & 248 & 261 & 246 & 178 \\
\hline
\end{tabular}

Note: MAIT (Manufacturing, Assembly, Integration \& Test), MRO (Maintenance, Repair \& Overhaul). Source: elaborated. 


\subsection{Artificial neural network (ANN)}

In this research, a Multi-Layer Perceptron (MLP) network is used, consisting of one input layer (13 neurons), one hidden layer (13 neurons) and one output layer (1 neuron). For the activation function, a tangent sigmoid function is used for the hidden layer and a linear function for the output layer. The training algorithm is backpropagation (Levenberg-Marquardt). The architecture is depicted in Figure 2, along with the input and output variables used.

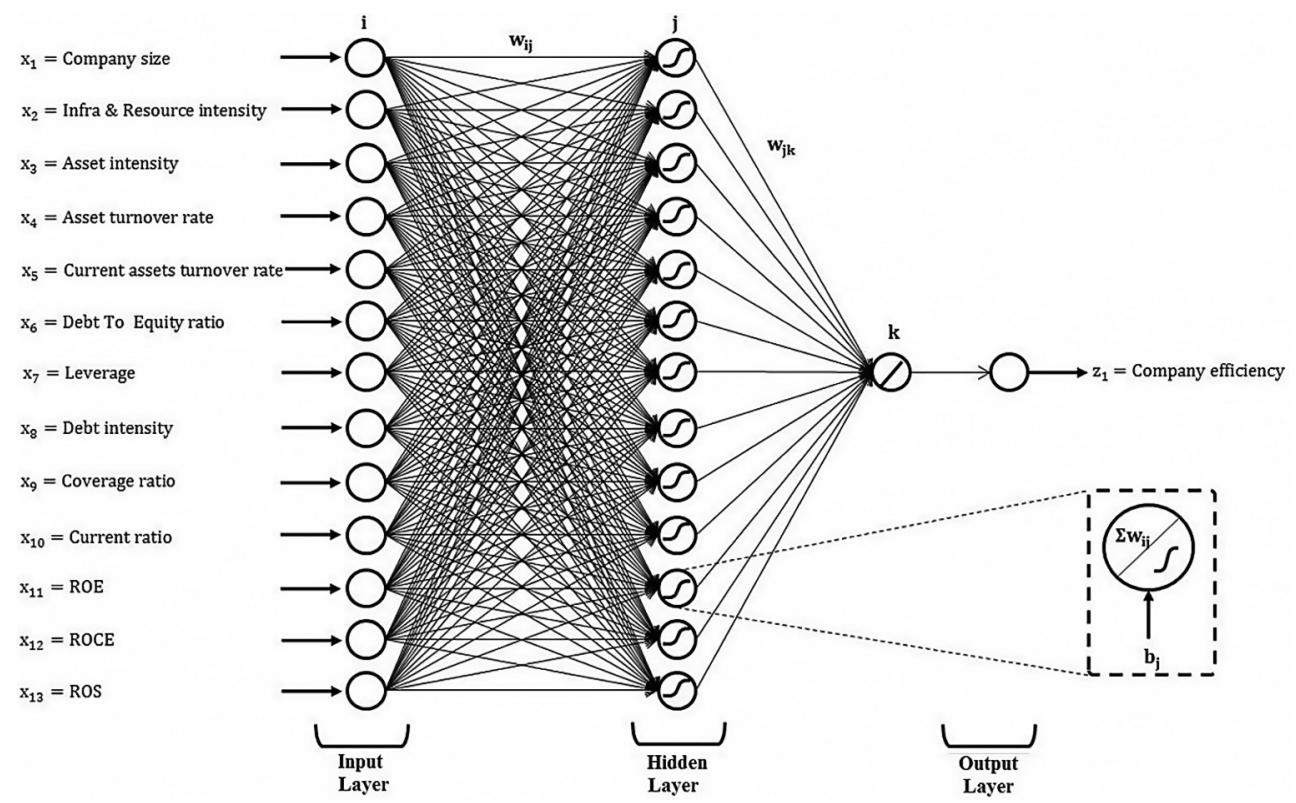

Fig. 2. Artificial neural network architecture

Source: elaborated.

After running the model, a close fit to reality is obtained, as shown in Figure $3(\mathrm{R}=0.93195)$. It can be seen that for the 0 and 1 points, values are concentrated horizontally, meaning that efficiency as measured by DEA could not be over 1 and below 0 .

For future research, a super-efficiency DEA model, which broadens the range of efficiency, may be applied; it would subsequently be expected that the ANN result, as displayed in Figure 3, would be smooth along the fitted regression line on such points.

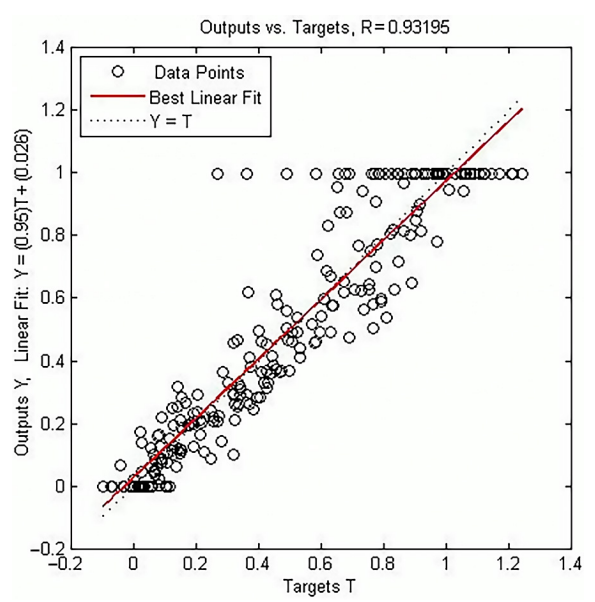

Fig. 3. Artificial neural network fit during validation Source: elaborated. 


\section{Conclusions}

In this study, we find continuity in terms of the four key components of the Spanish aerospace manufacturing value chain over the period 2008-2013, which explains on average $77.82 \%$ of the industry variance. The key drivers as indicated by the variance explained for each research question are: (a) ability to balance long- and short-term asset, capital and liquidity structures, (b) indebtedness capacity of the company for the level of assets held, (c) performance in returns, and (d) assets turnover capability. In terms of practical implications, the Spanish aerospace manufacturing value chain is following a number of managerial trends: (a) deleveraging, (b) weighting of non-current assets levels over current assets, and (c) transforming short-term liabilities into longterm liabilities. Those policies are reflected in a slight drop in performance in terms of returns (ROE, ROCE and ROS).

The next conclusion concerns the feasibility of measuring, benchmarking and analysing the financial management performance of companies using DEA efficiency as the only metric, following the model presented. Compared to the industry average, the top companies in terms of financial performance are: (a) younger, (b) moving from a smaller market share in the first half of the period to a higher share in the second, (c) less dependent on non-current assets for their operations, (d) more capable of transforming asset investments into sales, (e) more averse to equity than to debt, (f) using higher levels of short-term liabilities than long-term, $(\mathrm{g})$ better at covering non-current assets with equity and (h) excelling at performance in returns. Top financial performers increase their market share and excel at returns compared to the industry average, deploying policies focused on liquidity: (a) in the short term by increasing current assets levels and financing them with short-term liabilities, plus increasing assets turnover, and (b) over the long term, aligning equity to non-current assets, as well as reducing asset and debt intensity levels. Firms covering activities from the entire value chain (Engineering + MAIT + Services + MRO) are above the industry financial performance average for the analysed period (2008-2013), showing a better capacity to balance resources and optimize operations driving financial performance. Finally, only MAIT companies exhibit stability in their financial performance; for the rest of the groups there is a clear change between the first and second half of the analysed period. The reason for this is probably that their production is constant in order to keep on track in terms of delivery plans, and all the financial decisions were made prior to production. This supports the selection of a period where new developments take place.

The last contribution of this research is providing researchers and practitioners with a model to forecast company financial management performance based on financial statements information. It enables scenario analysis of the managerial decisions to be taken, such as modifying the level of debt, equity and assets, ramping up commercial campaigns, and/or decreasing the cost baseline.

These results and conclusions represent a breakthrough for the aerospace manufacturing industry, as it is the first such scientific research on financial performance in Spain. Additionally, this benchmarking and forecasting of financial performance yields not only 
information but also a methodology for the sector, thus facilitating financial decisionmaking while increasing accuracy.

Another important aspect of the study is the international potential of the findings; they are of interest not only to stakeholders of the case study. The model could be extrapolated to other countries, in order to test the validity of these findings in other regions, or to identify differences and their cause. Other sectors could also be examined.

As indicated by the conceptual framework and findings, further research should target causality. Companies from all Spanish SICs could be clustered using the model variables, thus allowing an analysis on the relationship between SIC code and findings for this sector. Going further, the country effect, could be regressed on industrial sectors. Another proposal consists of applying the model and techniques used in this research to the Spanish air transport value chain, with a particular focus on air transport companies (passengers and cargo), airports, services companies (handling, crew training, catering, computer reservation systems, etc.), lessors, travel agents and air navigation system providers. It would thus be possible to identify the link between the two value chains (manufacturing and air transport), in an attempt to discover propagation mechanisms of trends and policies between those two aerospace value chains.

A major limitation of this study is that it focuses on only one SIC, in a single country and during a certain time span. However, this opens up a range of opportunities to further test the model in other environments (industrial sectors and countries). More research may allow causality to be inferred in the relationship between country or industry effects and financial performance.

\section{References}

Adler, N.; Yazhemsky, E. 2010. Improving discrimination in data envelopment analysis: PCADEA or variable reduction, European Journal of Operational Research 202: 273-384.

https://doi.org/10.1016/j.ejor.2009.03.050

Azadeha, A.; Mianaeia, H.; Asadzadeha, S.; Saberib, M.; Sheikhalishahi, M. 2015. A flexible ANN-GA-multivariate algorithm for assessment and optimization of machinery productivity in complex production units, Journal of Manufacturing Systems 35: 46-75.

https://doi.org/10.1016/j.jmsy.2014.11.007

Bureau Van Dijk. 2015. SABI [online], [cited 23 March 2015]. Available from Internet: https:// sabi.bvdinfo.com/version-2015323/home.serv?product=sabineo

Campello, M. 2006. Debt financing: does it boost or hurt firm performance in product markets?, Journal of Financial Economics 82: 135-172. https://doi.org/10.1016/j.jfineco.2005.04.001

Ciampi, F.; Gordini, N. 2008. Using economic-financial ratios for small enterprise default prediction modelling: an empirical analysis, in Oxford Business \& Economics Conference, 22-24 June 2008, Oxford, United Kingdom.

Devinney, T. M.; Yip, G. S.; Johnson, G. 2010. Using frontier analysis to evaluate company performance, British Journal of Management 21: 921-938.

https://doi.org/10.1111/j.1467-8551.2009.00650.x

Delen, D.; Kuzey, C.; Uyar, A. 2013. Measuring firm performance using financial ratios: a decision tree approach, Expert Systems with Applications 40: 3970-3983.

https://doi.org/10.1016/j.eswa.2013.01.012 
Halici, A.; Umut Erham, D. 2013. Structuring strategic management with ratio analysis method: a case study in the transition to SME TFRS process, Procedia - Social and Behavioral Sciences 99: 947-955. https://doi.org/10.1016/j.sbspro.2013.10.568

Halkos, G. E.; Tzeremes, N. G. 2012. Industry performance evaluation with the use of financial ratios: an application of bootstrapped DEA, Expert Systems with Applications 39: 5872-5880. https://doi.org/10.1016/j.eswa.2011.11.080

Ho, C.-T. B.; Wu, D. D. 2009. Online banking perfomance evaluation using data envelopment analysis and principal component analysis, Computers \& Operations Research 36: 1835-1842. https://doi.org/10.1016/j.cor.2008.05.008

Hofmann, E.; Lampe, K. 2013. Financial statement analysis of logistics service providers: ways of enhancing performance, International Journal of Physical Distribution \& Logistics Management 43(4): 321-342. https://doi.org/10.1108/IJPDLM-08-2012-0229

ICEX. 2016. Spain: Business opportunities in aerospace [online], [cited 15 May 2017]. ICEX. Available from Internet: http://www.investinspain.org/invest/wcm/idc/groups/public/documents/ documento/mde1/mzy3/ edisp/doc2015367125.pdf

Iyer, K. C.; Banerjee, P. S. 2016. Measuring and benchmarking managerial efficiency of project execution schedule performance, International Journal of Project Management 34: 219-236. https://doi.org/10.1016/j.ijproman.2015.10.008

Kayo, E.; Kimura, H. 2011. Hierarchical determinants of capital structure, Journal of Banking and Finance 35: 358-371. https://doi.org/10.1016/j.jbankfin.2010.08.015

Kheirkhah, A.; Azadeh, A.; Saberi, M.; Azaro, A. 2013. Improved estimation of electricity demand function by using of artificial neural network, principal component analysis and data envelopment analysis, Computers \& Industrial Engineering 64: 425-441.

https://doi.org/10.1016/j.cie.2012.09.017

Lampe, K.; Hofmann, E. 2014. Understanding the cost of capital of logistics service providers: an empirical investigation of multiple contingency variables, Logistics Research 7(119): 1-25. https://doi.org/10.1007/s12159-014-0119-7

Lee, S. G.; Ma, Y. S.; Thimm, G. L.; Verstraeten, J. 2008. Product lifecycle management in aviation maintenance, repair and overhaul, Computers in Industry 59: 296-303.

https://doi.org/10.1016/j.compind.2007.06.022

Liargovas, P.; Skandalis, K. 2010. Factors affecting firm performance: the case of Greece, Global Business Management Research: An International Journal 2(3): 184-197.

Madrid-Guijarro, A.; García Pérez de Lema, D.; van Auken, H. 2011. An analysis of non-financial factors associated with financial distress, Entrepreneurship and Regional Development 23(3-4): 159-186. https://doi.org/10.1080/08985620903233911

Margaritis, D.; Psillaki, M. 2010. Capital structure, equity ownership and firm performance, Journal of Banking and Finance 34(3): 621-632. https://doi.org/10.1016/j.jbankfin.2009.08.023

Marketline. 2012. Aerospace \& defense in Spain. A report on industry profile. London: Marketline.

Marketline. 2014. Aerospace \& defense in Spain. A report on industry profile. London: Marketline.

Ministry of Industry, Energy and Tourism. 2016. Presentaciones sectoriales. Sector construcción aeronáutica y espacial [online], [cited 15 May 2017]. MINETAD. Available from Internet: 
http://www.minetad.gob.es/es-ES/IndicadoresyEstadisticas/Presentaciones\%20sectoriales/Construcción $\% 20$ aeronáutica $\% 20 \mathrm{y} \% 20$ espacial.pdf

Ministry of Economy, Industry and Competitiveness. 2010. Plan integral de politica industrial 2020 [online], [cited 15 May 2017]. Secretariat Generale of Industry. Available from Internet: http://www.minetad.gob.es/es-es/gabineteprensa/notasprensa/documents/planintegralpoliticaindustrial2020.pdf

Mohd-Sulaiman, A. 2013. Financial reporting failures, board's competency and effectiveness, International Journal of Disclosure and Governance 10: 155-174.

https://doi.org/10.1057/jdg.2013.5

Morgan, N.; Vorhies, D.; Mason, C. 2009. Market orientation, marketing capabilities and firm performance, Strategic Management Journal 30: 909-920. https://doi.org/10.1002/smj.764

National Statistics Institute. 2017. Industrial Companies Survey, INE [online], [cited 15 May 2017]. Available from Internet: http://www.ine.es/dyngs/INEbase/en/operacion.htm?c=Estadisti ca_C\&cid $=1254736143952 \&$ menu $=$ ultiDatos\&idp $=1254735576715$

Shue, L.; Chen, C.; Shiue, W. 2009. The development of an ontology-based expert system for corporate financial rating, Expert Systems with Applications 36: 2130-2142.

https://doi.org/10.1016/j.eswa.2007.12.044

Society of Automotive Engineers (International Aerospace Quality Group). 2015. OASIS [online], [cited 20 January 2015]. Available from Internet: https://www.sae.org/?PORTAL_CODE=IAQG

Song, M.; Wu, J.; Wang, Y. 2011. An extended aggregated ratio analysis in DEA, Journal of Systems Science and Systems Engineering 20(2): 249-256.

https://doi.org/10.1007/s11518-011-5162-1

Sueyoshi, T.; Goto, M. 2010. Measurement of a linkage among environmental, operational, and financial performance in Japanese manufacturing firms: a use of data envelopment analysis with strong complementary slackness condition, European Journal of Operational Research 207: 1742-1753. https://doi.org/10.1016/j.ejor.2010.07.024

TEDAE: Asociación Española de Empresas Tecnológicas de Defensa, Aeronáutica y Espacio (TEDAE). 2014. Aeronáutica en cifras 2013 [online], [cited 20 January 2015]. Available from Internet: https://www.tedae.org/uploads/old/files/pdf-online/cifrastedae2013/mobile/index.html

Tehrani, R.; Mehragan, M.; Golkani, M. 2012. A model for evaluating financial performance of companies by data envelopment analysis, International Business Research 5(8): 8-16.

https://doi.org/10.5539/ibr.v5n8p8

Tosun, O. 2012. Using data envelopment analysis-neural network model to evaluate hospital efficiency, International Journal of Productivity and Quality Management 9(2): 245-257. https://doi.org/10.1504/IJPQM.2012.045194

Vishnani, S.; Shah, B. Kr. 2007. Impact of working capital managerial policies on corporate performance an empirical study, Global Business Review 8(2): 267-281.

https://doi.org/10.1177/097215090700800206

Wang, Y.; Li, Y. M.; Jan, C.L.; Chang, K. W. 2013. Evaluating firm performance with balanced scorecard and data envelopment analysis, WSEAS Transactions on Business \& Economics 10(1): 24-39.

Yeh, C. C.; Chi, D. J.; Hsu, M. F. 2010. A hybrid approach of DEA, rough set and support vector machines for business failure prediction, Expert Systems with Applications 37: 1535-1541. https://doi.org/10.1016/j.eswa.2009.06.088 
Rubén Elvira HERRANZ is an Adjunct Professor of Mathematics at Instituto de Estudios Bursátiles (Madrid, Spain), and previously Adjunct Professor of Project Management and Economics in Aerospace Engineering School at Universidad Politécnica de Madrid (Madrid, Spain). Also employed by Airbus since more than 10 years, the last ones as Program Manager. He holds a PhD degree in Business Administration from Rey Juan Carlos University (Madrid, Spain), as well as two MS and MBA, plus a Bachelor in Aerospace Engineering. Certified as PMP ${ }^{\circledR}$ (Project Management Professional). His research interests are in the areas of operation management, finance and economics. He has attended and participated in various international congresses, holding some publications in journals.

Pablo García ESTÉVEZ is an Associate Professor of Finance at CUNEF and IE Business School (Madrid, Spain). Also is a senior financial advisor to companies. He holds a PhD degree in Economy from Complutense University (Madrid, Spain) and MS in Financial Firms Management. He has published nine books regarding M\&A, Stock Markets and Financial Management as well as various articles. His research line targets the application of Artificial Neural Networks to financial markets.

María Auxiliadora de Vicente y OLIVA is an Associate Professor of Statistics at Rey Juan Carlos University (Madrid, Spain). She holds a PhD and BA in Mathematics from Complutense University (Madrid, Spain). She performs various research projects with the Spanish Public Administration either as lead researcher or adjunct researcher. Counting with several publications in journals and participation on various conferences, both national and international. Her research lines targets the application of multicriteria decision analysis to economic and financial topics.

Rahul DÉ is the Hewlett-Packard Chair Professor in ICT for Sustainable Economic Development, in the Decision Sciences and Information Systems Area at the Indian Institute of Management Bangalore. He holds a PhD from the University of Pittsburgh, Katz Graduate School of Business. Since 1990, he has taught Information Systems courses at various universities in the United States, India, Spain, France, Sweden and Norway. His research interests are in ICT for development, open source and e-Government systems. He has published two books and over 60 articles in international journals, as chapters in books and in refereed conference proceedings. He has served on the Board of IIM Bangalore, and continues to serve on the Boards of Institute for Development and Research in Banking Technology, Hyderabad, and sflc.in (Software Freedom Law Centre in India). He serves on the editorial board of the journals Information \& Management and Government Information Quarterly. He received the Outstanding Paper Award at the Eight International Conference on Electronic Government, EGOV 2009, at Linz, Austria. He was awarded the Rene Wagenaar Outstanding Paper Award at the Sixth International Conference on Electronic Government, EGOV 2007, in Regensburg, Germany. In July 2010, he received the Best Professor in Information Systems Award at Asia's Best B-School Awards in Singapore. 